УДК 656.61 : 347.797 (438) “19”

\author{
Dworas-Kulik Judyta \\ Dr., Asystent, \\ Katedra Historii Ustroju i Prawa, \\ Katolicki Uniwersytet Lubelski Jana Pawła II, \\ Lublin, Polska, \\ judytadworas@kul.lublin.pl
}

\title{
PRZYWILEJ MORSKI W POLSCE W OKRESIE MIĘDZYWOJENNYM NA TLE PORÓWNAWCZYM
}

Celem artykułu jest zbadanie przywilejów morskich w okresie międzywojennym. W opracowaniu wykorzystano metody historyczne i prawne. Rozwój transportu morskiego na przełomie XIX i XX wieku przyczynił się do międzynarodowej unifikacji prawa morskiego w zakresie przywilejów na statku i hipoteki morskiej. Potrzeba ujednolicenia przepisów wynikała z konieczności realnego zapewnienia wierzycielom zaspokojenia ich roszczeń, bowiem różnorodność przepisów poszczególnych państw, szczególnie ilość przywilejów morskich, która powstała pod rządem różnych systemów prawnych oraz hierarchia ich stosowania ograniczały znaczenie instytucji hipoteki morskiej. Powstawanie przywilejów morskich z mocy prawa uniemożliwiało umowne i trwałe określenie treści stosunku prawnego. Tym celom służyła instytucja hipoteki morskiej, która ustępowała pierwszeństwa przywilejom morskim powstającym z mocy prawa. Treść przepisów międzynarodowych stała się podstawą do kształtowania polskich przepisów dotyczących wyżej wskazanych instytucji prawa morskiego. Te jednakże powstały dopiero z początkiem lat $60 \mathrm{XX}$ wieku, stąd też bogata literatura przedmiotu dotyczy głównie okresu z przełomu XX i XXI wieku. Problematyka instytucji przywileju morskiego w okresie dwudziestolecia międzywojennego była dotąd jedynie sygnalizowana, dlatego też niniejsza publikacja ma na celu kompleksowe omówienie zagadnienia.

Słowa kluczowe: zabezpieczenie mienia morskiego, uprzywilejowanie wierzyciela, uprawnienia do statku morskiego, pierwszeństwo w zaspokajaniu roszczeń morskich, wierzytelności uprzywilejowane.

Дворас-Кулик Юдіта, доктор філософії, асистент кафедри історії політики та права, Люблінський католиџький університет Іоанна Павла II, Люблін, Польщза

Морські привілеї Польщі у міжвоснний період: порівняльний аналіз

Метою статті $є$ вивчення морських привілеїв у міжвоєнний період. У дослідженні застосовано історичні та юридичні методи. Розвиток морського 
транспорту в кін. XIX і поч. XX ст. сприяв уніфікації міжнародного морського права щодо пільг на судні і морській іпотеці. Необхідність узгодження правил випливала з потреби реального забезпечення задоволення вимог кредиторів, оскільки різноманітність національних законів, зокрема, кількість привілеїв морських, яка була створена урядами в різних правових системах, та ієрархія їх застосування обмежували значення важливості морських іпотечних інститутів. Виникнення морських пільг, за законом, перешкоджало договірному та постійному визначенню змісту правових відносин. Цій меті слугував інститут морської іпотеки, що поступився місцем привілеям морських прав, створених законом. Зміст міжнародних правил став основою для розвитку польських правил, що стосуються згаданих вище інститутів морського права. Вони, однак, виникли лише на поч. 60-х pp. XX ст., 3 того часу до рубежу XX та XXI ст. сформувався значний масив літератури. Питання ж про заставні інститути морського привілею в міжвоєнне двадцятиліття було до цього тільки зазначене, тому дана публікація спрямована на його комплексний розгляд.

Ключові слова: захист морської власності, привілей кредитора, права на морський корабель, пріоритет у задоволенні морських вимог, привілейовані борги.

Dworas-Kulik Judyta, PHD, Assistant, Department of History of Politics and Law, John Paul II Catholic University of Lublin, Lublin, Poland

\section{Maritime liens in Poland in the interwar period against a comparative background}

The purpose of the article is to study maritime privileges in the interwar period. The study uses historical and legal methods. The development of maritime transport at the end of the nineteenth and early twentieth centuries contributed to the unification of international maritime law regarding privileges on ships and maritime mortgages. The need for harmonization of rules resulted from the need for real satisfaction of claims of creditors, since the diversity of national laws, in particular, the number of privileges of the sea, which was created by governments in different legal systems, and the hierarchy of their application limited the importance of the importance of marine mortgage institutions. The emergence of marine privileges under the law prevented a contractual and permanent definition of the content of legal relations. This goal is served by the Maritime Mortgage Institution, which gave way to privileges of maritime rights created by law. The content of the international rules became the basis for the development of Polish rules relating to the above-mentioned institutions of the law of the sea. They, however, arose only in the early 60's of the twentieth century, from that time to the turn of the twentieth and twenty-first century formed a large array of literature. The question of mortgage institutes of maritime 
privilege in the interwar twoteenth century was only mentioned before, so this publication is aimed at its comprehensive consideration.

Key words: protection of maritime property, privilege of the creditor, entitlement to a sea-going ship, priority in satisfying maritime claims, privileged debts, rights on a ship.

Дворас-Кулик Юдита, доктор философии, ассистент кафедрь истории политики и права, Люблинский католический университет Иоанна Павла II, Люблин, Польша

\section{Морские привилеи Польши в межвоенный период: сравнительный} анализ

Целью статьи является изучение морских привилегий в межвоенный период. В исследовании применены исторические и юридические методы. Развитие морского транспорта в кон. XIX и нач. XX в. способствовало унификации международного морского права по льготам на судне и морской ипотеке. Необходимость согласования правил вытекала из необходимости реального обеспечения удовлетворения требований кредиторов, поскольку разнообразие национальных законов, в частности, количество привилегий морских, которая была создана правительствами в различных правовых системах, и иерархия их применения ограничивали значение важности морских ипотечных институтов. Возникновение морских льгот по закону препятствовало договорном и постоянном определению содержания правовых отношений. Этой цели служит институт морской ипотеки, уступил место привилегиям морских прав, созданных законом. Содержание международных правил стало основой для развития польских правил, касающихся упомянутых выше институтов морского права. Они, однако, возникли лишь в нач. 60-х гг. ХХ в. С тех пор к рубежу XX и XXI вв. сформировался значительный массив литературы. Вопрос же о залоговых институтах морской привилегии в межвоенное двадцатилетие было до этого только указано, поэтому данная публикация направлена на его комплексное рассмотрение.

Ключевые слова: защита морской собственности, привилегия кредитора, права на морской корабль, приоритет в удовлетворении морских требований, привилегированные долги.

Wprowadzenie. Przywileje morskie w okresie dwudziestolecia międzywojennego oznaczały to samo, co przywileje na statku. Pod pojęciem tym rozumiano prawa zabezpieczające określone wierzytelności, które były związane z eksploatacją statku [więcej na ten temat: 13, s. 49-51]. Uprzywilejowanym wierzytelnościom przyznawano prawo pierwszeństwa $\mathrm{W}$ zaspokojeniu roszczeń $\mathrm{z}$ tegoż statku i innych składników majątku morskiego [zob. 21, s. 91; por. 17], stąd też 
stanowiły one wyjątek od zasady równości wszystkich wierzycieli. Uprzywilejowanie wierzytelności powstawało z mocy prawa, bez konieczności wpisu statku do rejestru okrętowego, tak jak to miało miejsce w przypadku hipoteki morskiej. Stopień uprzywilejowania wierzycieli był różny, bowiem zależał od rangi danego przywileju morskiego przyznanego przez ustawodawcę. Co więcej, treść przywilejów morskich oraz ich hierarchia zależała m.in. od obywatelstwa wierzycieli uprzywilejowanych lub od bandery statku, o czym bliżej w dalszej części artykułu. Powyższe okoliczności miały wpływ na ich różną skuteczność, a także stopień zabezpieczenia interesów uprzywilejowanych wierzycieli [zob. 13, s. 53, por. 17]. Przywilej morski wygasał wraz $\mathrm{z}$ zaspokojeniem wierzyciela. Zaznaczyć należy, iż niejawny charakter przywilejów morskich skutkował tym, że uprzywilejowany wierzyciel mógł nie wiedzieć, iż przysługuje mu szczególne pierwszeństwo względem pozostałych dłużników [por. 20, s. 498-499]. Zaznaczyć również należy, iż przywilej morski jako ustawowe prawo zastawu był wiążący pomimo zmiany osoby wierzyciela lub armatora, nawet jeśli nabywca statku działał $\mathrm{w}$ dobrej wierze.

Prawne regulacje dotyczące przywileju morskiego obowiązujące na ziemiach polskich po odzyskaniu niepodleglości. Polska po odzyskaniu niepodległości w 1918 r. z uwagi na bardzo długi okres zaborów nie posiadała własnych aktów normatywnych, które mogłyby zastąpić kodeksy pozaborcze. Dawne ustawodawstwo polskie stało się przestarzałe i całkowicie niedostosowane do potrzeb ustrojowo prawnych międzywojennej Polski, dlatego też w celu utrzymania porządku prawnego na terytorium kraju przyjęto zasadę ciągłości prawa. Podstawowym aktem normatywnym regulującym kwestie związane z przywilejem morskim była IV Księga HBG (niemiecki kodeks handlowy z 10 maja 1897 r., §§ 474-9050 [zob. 10; por. 12], recypowana do ustawodawstwa Rzeczypospolitej Polskiej ustawą z dnia 1 sierpnia 1919 r. o zarządzie byłej dzielnicy pruskiej (Dz. Praw Państwa Polskiego Nr 64 poz. 385) [zob. 17].

Przepisy dotyczące przywilejów morskich na statku zostały zawarte w §§ 754-777 HBG [por. 16, s. 13-14]. Miały one pierwszeństwo przed wszystkimi innymi wierzytelnościami zastawnymi (§ 776 HBG). Zgodnie $\mathrm{z} \quad \S 754$ HBG wyznaczającym hierarchię przywilejów, w pierwszej kolejności były uprzywilejowane wierzytelności wynikające z kosztów strzeżenia i zachowania okrętu oraz jego przynależności, które nie należały do kosztów egzekucyjnych, od momentu wprowadzenia okrętu do ostatniego portu, w razie sprzedaży statku morskiego w drodze egzekucji (§ 754 ust. 1, §766 HBG). Do kolejnej grupy wierzytelności uprzywilejowanych, gdzie $\mathrm{z}$ jednej strony $\mathrm{o}$ pierwszeństwie decydowały wierzytelności z ostatniej podróży ( $\$ 767 \mathrm{HBG}$ ), zaś z drugiej strony zgodnie z treścią §§768-769 HBG przy wierzytelnościach odnoszących się do tej samej podróży, tj. rozpoczynającej się lub opartej na nowej umowie przewozowej albo następującej po wyładunku (§ 757 HBG) pierwszeństwo wynikało wprost z kolejności wynikającej 
ze struktury § 754 HBG zaliczano publiczne daniny okrętowe, żeglarskie i portowe, w szczególności opłaty beczkowe, świetlane, kwarantannowe oraz portowe (ust.2). Dalej $\S 754$ ust. 3 HBG ustawodawca wskazywał na wierzytelności załogi statku morskiego, powstające z umów służbowych i najemniczych. Wierzycielom uprzywilejowanym w oparciu o treść $\S 754$ ust. 3 przysługiwało jednocześnie ustawowe prawo zastawu w stosunku do wierzytelności powstałych z poprzednich podróży, o ile podróże statku odbywały się na podstawie tej samej umowy służbowej lub najemnej (§ $758 \mathrm{HBG}$ ). Co więcej, takim wierzycielom przysługiwało równe prawo pierwszeństwa (§ $767 \mathrm{HBG),} \mathrm{bowiem} \mathrm{na} \mathrm{prawa} \mathrm{wierzyciela} \mathrm{statku} \mathrm{nie} \mathrm{miała} \mathrm{żadnego} \mathrm{wpływu}$ sytuacja, w której armator był zarazem odpowiedzialnym za tę wierzytelność przy jej powstaniu lub później (§ 762). Następnymi wierzytelnościami uprzywilejowanymi były należności pilotów oraz koszty schronienia, niesienia pomocy, wykupu i koszty reklamacyjne (ust. 4). Kolejnymi zaś składki powstałe w skutek awarii okrętu (ust. 5), wierzytelności wierzycieli bomberyjnych, którym oddano $\mathrm{w}$ zastaw statek oraz wierzytelności wynikające $\mathrm{z}$ wszelkich innych umów kredytowych zwartych przez kapitana statku $\mathrm{w}$ nagłej potrzebie podczas postoju statku poza portem ojczystym [zob. § 528-541 HBG], nawet wówczas gdy kapitan statku był właścicielem lub współwłaścicielem okrętu. $Z$ powyższymi wierzytelności zrównane były wierzytelności wynikające $\mathrm{z}$ niezbędnych dostaw albo świadczeń powstałych $\mathrm{w}$ wypadkach nagłych celem zachowania okrętu bądź zrealizowania podróży bez konieczności udzielania kredytów kapitanowi statku, o czym wyżej mowa (ust. 6). Zaznaczyć w tym miejscu należy, iż wierzytelności wskazane $w \quad \S 754$ ust. 4-6 HBG zaspokajane były według kolejności ich powstania, czyli pierwszeństwo miały wierzytelności powstałe później, natomiast jeśli powstały one w tym samym czasie wolą ustawodawcy wierzyciele mieli te same prawa. Co istotne, różne czynności prawne zawarte przez kapitana statku w związku z ta samą awarią okrętu traktowano jak dokonane jednocześnie (§ $769 \mathrm{HBG})$. Inne rodzajem wierzytelności były należności powstałe $\mathrm{z}$ powodu niedostarczenia lub uszkodzenia towarów ładownych i bagażu podręcznego [zob. § 673 ust.2 HBG] (ust. 7). Przepis $§ 754$ ust. 8 HBG wskazywał również na uprzywilejowanie wierzytelności wcześniej nie wymienionych, które wynikały z czynności prawnych zawartych przez kapitana statku $\mathrm{z}$ mocy ustawowego uprawnienia, nie zaś $\mathrm{z}$ na podstawie pełnomocnictwa szczególnego [zob. § 486 ust. 1 pkt 10]. Równolegle do poprzednich powstawały wierzytelności $\mathrm{z}$ tytułu niewykonania, niezupełnego wykonania lub wadliwego wykonania umowy przez armatora statku, o ile wykonanie umowy należało do służbowych obowiązków kapitana statku [zob. § 486 ust. 1 pkt 2] (ust. 8). Do katalogu wierzytelności uprzywilejowanych zaliczano także wierzytelności powstałe w skutek zawinienia członka załogi statku, także będącego jednocześnie właścicielem lub współwłaścicielem statku [zob. § 485 i § 486 ust. 1 pkt 3] (ust. 9) oraz wierzytelności przysługujące przeciwko armatorowi powstałe $\mathrm{w}$ związku $\mathrm{z}$ przepisami $\mathrm{o}$ 
ubezpieczeniu od nieszczęśliwych wypadków i z przepisami o ubezpieczeniu inwalidów (ust. 10), przy czym te ostatnie pierwszeństwa ustępowały wszystkim innym wierzytelnościom uprzywilejowanym bez względu na czas ich powstania (§ $770 \mathrm{HBG})$.

Wierzycielom, którym nie oddano statku w zastaw bomberyjny przysługiwało ustawowe prawo zastawu na statku i innych składnikach majątku morskiego, które można było dochodzić względem każdego posiadacza statku (§ 755-756 HBG). Zaspokojenie wierzyciela okrętu następowało poprzez realizację roszczenia (§ $771 \mathrm{HBG}$ ) lub na podstawie przepisów o egzekucji przymusowej. Jednakże armator nie ponosił odpowiedzialności za zaspokojenie wierzycieli wbrew kolejności wynikającej z ustawy, jeśli nie miał świadomości, że działa $\mathrm{z}$ pokrzywdzeniem wierzycieli, którym przysługuje pierwszeństwo ( $\$ 772$ HBG). Skargę można było wytaczać zarówno względem armatora jaki i kapitana statku, nawet jeśli statek znajdował się w tym czasie w porcie ojczystym, o którym mowa w § 480 HBG (§ 761), bowiem wyrok zapadły wobec jednego z nich był wiążący również dla drugiego. Zaznaczyć w tym miejscu należy, iż nie miało znaczenia czy armator był przedsiębiorcą, czy spółką prawa handlowego (§ 763). Co więcej, armator mógł stać się osobiście odpowiedzialny za wierzytelności, jeżeli pomimo powzięcia informacji o obciążeniu statku wierzytelnością uprzywilejowaną wysłał okręt w kolejną podróż, chociaż interes wierzyciela tego nie wymagał. W takim przypadku armator odpowiadał do sumy, która przypadałaby danemu wierzycielowi po podziale uzyskanej kwoty pomiędzy wierzycieli zgodnie $\mathrm{z}$ ustawowym stopniem pierwszeństwa (§ $774 \mathrm{HBG}$ ).

Cechą charakterystyczną przepisów niemieckiego HBG był brak przywileju dla stoczni, zabezpieczającego jej roszczenia z tytułu nieuiszczenia części ceny kupna statku, jak też z tytułu zapłaty za wybudowanie oraz naprawienie statku [16, s. 14; por. 26, s. 89-99].

Ksztaltowanie się polskich przepisów dotyczących instytucji przywileju morskiego. Ze Sprawozdania Prezydenta Komisji Kodyfikacyjnej za okres od 1 czerwca 1934 do 31 marca 1937 roku [zob. 9, s. 21] wynika, iż kodyfikacja prawa morskiego miała istotne znaczenie, ponieważ poniemieckie ustawodawstwo co do zasady obowiązywało na ziemiach byłego zaboru pruskiego. W pozostałych dzielnicach Polski problematyka prawa morskiego, w tym przywilejów morskich nie została uregulowana. Pomimo jednak formalnego podziału ustawodawstw na poszczególne dzielnice niemieckie przepisy dotyczące prawa morskiego stosowano powszechnie na terenie całej Rzeczypospolitej Polskiej. Pilna potrzeba wprowadzenia jednolitych uregulowań w tym zakresie wynikała zatem ze swego rodzaju luki prawnej powstałej w skutek przejęcia do polskiego porządku prawnego ustawodawstwa państw zaborczych na obszarach centralnej, południowej i wschodniej Polski. 
Mając na uwadze powyższe okoliczności wskazać zatem należy, iż przepisy IV Księgi HBG pełniły dwie istotne funkcje. $Z$ jednej strony spełniały rolę norm międzynarodowych $\mathrm{w}$ kontaktach $\mathrm{z}$ obywatelami innych państw $\mathrm{z}$ uwagi na brak polskich unormowań międzynarodowych $w$ tym zakresie. Natomiast $\mathrm{z}$ drugiej strony były prawem właściwym $\mathrm{w}$ stosunkach prywatnych wewnętrznych [więcej na ten temat: 27 , s. 4-53; por. 18 , s. 288], próbując w ten nieporadny sposób zastąpić brakujące regulacje prawa prywatnego międzydzielnicowego. $\mathrm{Na}$ marginesie zaznaczę, iż jednolite uregulowania prawa międzynarodowego powstały dopiero na gruncie ustawy z dnia 2 sierpnia 1926 r. O prawie właściwem dla stosunków prywatnych międzynarodowych (Dz. U. 1926, Nr 101, poz. 581, dalej p.p.mn.). Zgodnie z Prawem prywatnym międzynarodowym z $1926 \mathrm{r}$. właściwość prawa wynikała $\mathrm{z}$ obywatelstwa, zatem treść i hierarchia przywilejów morskich była kształtowana przez ustawodawstwa ojczyste wierzycieli (art. 1, art. 12 ust. 1 p. p. mn.).

Prace nad ujednoliceniem przepisów z zakresu prawa morskiego rozpoczęły się w roku 1932, pomimo że Komisja Kodyfikacyjna działalność unifikacyjną prawa rozpoczęła już 1919 r. (zob. ustawa z dnia 3 czerwca 1919 roku o komisji kodyfikacyjnej (Dz. Praw Państwa Polskiego Nr 44, poz. 315). W skład podkomisji prawa morskiego i rzecznego wchodzili : przewodniczący S. Wróblewski, jego zastępca B. Hełczyński, referent J. Sułkowski oraz członkowie J. Mrozowski i E. Waśkowski. Ze sprawozdania z działalności Komisji Kodyfikacyjnej wynika, iż opracowanie projektu prawa morskiego i rzecznego powierzono prof. Józefowi Sułkowskiemu [zob. 8; por. 19, s. 6-7]. Wskazać należy, iż projekt Sułkowskiego oprócz przepisów $\mathrm{z}$ dziedziny prawa prywatnego zawierał również normy proceduralne oraz normy międzynarodowego prawa prywatnego, które regulowały niektóre przypadki kolizji norm prawnych oraz sankcje karne w przypadku naruszenia ważniejszych przepisów [zob. 17]. Przepisy dotyczące przywilejów morskich na statku i ładunku morskim zostały uregulowane w piątym dziale związanym z prawami rzeczowymi na statku i ladunku [9, s. 23]. W kwestii opracowywania polskich przepisów dotyczących przywilejów morskich za wzorzec posłużyły przepisy Konwencji międzynarodowej o ujednoliceniu niektórych zasad, odnoszących się do przywilejów i hipotek morskich (podpisana w Brukseli dnia 10 kwietnia 1926 r., Dz. U. Nr 33 poz. 260), o czym bliżej w dalszej części artykułu.

Prace nad ujednoliceniem prawa morskiego przerwał wybuch wojny, dlatego też projekt Sułkowskiego nie wszedł $w$ życie. Natomiast $w$ powojennym ustawodawstwie nie odegrał znaczącej roli z uwagi na zmianę sytuacji społecznogospodarczej kraju. Typowo polskie uregulowania dotyczące przywilejów morskich zostały ustanowione dopiero na gruncie kodeksu morskiego z 1961 r. [zob. 7; więcej na temat: 14 , s. $9-76$; por. 22 , s. $129-142$; por. 23 , s. 98-101; por. 24 , s. 219-238; por. 15 , s. $97-101]$ 
Regulacje międzynarodowe dotyczące przywileju morskiego w okresie międzywojennym. Konwencje międzynarodową o ujednoliceniu niektórych zasad, odnoszących się do przywilejów i hipotek morskich z 1926 r. (Dz. U. Nr 33 poz. 260) ratyfikowano do ustawodawstwa polskiego ustawą z dnia 20 lutego $1936 \mathrm{r}$. w sprawie ratyfikacji międzynarodowej konwencji o ujednoliceniu niektórych zasad, odnoszących się do przywilejów i hipotek morskich. Ustawę podpisano w Brukseli dnia 10 kwietnia 1926 r. (Dz. U. Nr 15 poz. 137), jednak nie wprowadzono ich do wewnętrznego porządku prawnego [zob. 20, s. 498; por. 16, s. 14], dlatego też na gruncie niniejszego opracowania regulacje prawne zawarte $\mathrm{w}$ konwencji $\mathrm{w}$ zakresie przywileju morskiego stanowią tło porównawcze dla uregulowań stosowanych $\mathrm{w}$ Polsce w okresie dwudziestolecia międzywojennego.

$\mathrm{Na}$ marginesie wskazać należy, iż celem międzynarodowej konwencji o ujednoliceniu niektórych zasad, odnoszących się do przywilejów i hipotek morskich (Dz. U. Nr 33 poz. 260), było przede wszystkim ograniczenie liczby przywilejów, ustalenie ich kolejności, a przez to wyznaczenie ściśle określonego miejsca dla hipoteki morskiej. Ujednolicenie norm prawnych z zakresu przywilejów na statku i hipoteki morskiej miało zlikwidować stan niepewności sytuacji prawnej, jak również kredytowej przedsiębiorstw okrętowych trudniących się żeglugą morską, bowiem przywileje wyliczone $\mathrm{w}$ konwencji miały bezwzględne pierwszeństwo przed zarejestrowaną hipoteką morską [zob. 17]. Potrzeba unormowania wyżej wymienionych zagadnień wynikała z braku jawności przywilejów morskich, ich dużej liczby oraz odmiennym traktowaniu w poszczególnych ustawodawstwach. Zakres rzeczowy postanowień konwencji obejmował statki eksploatowane przez właściciela, armatora nie będącego właścicielem i jednostkę czarterującą [bliżej na ten temat; 25, s. 33-41].

Katalog uprzywilejowanych wierzytelności ciążących na statku bez względu na to, kto w danej chwili był wierzycielem uprzywilejowanym (art. 8) został zawarty $\mathrm{w}$ art. 2 konwencji. Uwzględniono w nim koszty sądowe należne Państwu oraz wydatki, które zostały poniesione we wspólnym interesie wierzycieli na konserwację statku, albo wydatki poniesione na koszty przeprowadzenia sprzedaży i podziału uzyskanej ceny. Ponadto wyszczególniono opłaty tonażowe, latarniane lub portowe, a także innego rodzaju opłaty i podatki publiczne, w tym opłaty pilotowe, koszty nadzoru i konserwacji od chwili wejścia statku do ostatniego portu. W art. 2 ust. 2 konwencja wskazywała wierzytelności, powstałe z umowy o najem z kapitanem, załogą oraz innymi osobami przyjętymi do służby na statek. W kojonym ustępie tego przepisu wymieniono wynagrodzenia należne za ratowanie i pomoc, jak również składki należne od statku w awariach wspólnych (art. 2 ust. 3). Przepis art. 2 ust. 4 uprzywilejowywał wierzytelności wynikające $\mathrm{z}$ odszkodowania za zderzenia $\mathrm{i}$ inne wypadki nawigacyjne oraz za szkody wyrządzone urządzeniom portowym, dokom i drogom żeglownym, a także odszkodowania za uszkodzenia cielesne 
pasażerów i załogi oraz odszkodowania za straty lub awarie ładunku bądź bagażu. W myśl przepisów konwencji ostatnią grupą wierzytelności uprzywilejowanych były wierzytelności powstałe z zawartych umów lub transakcji, które zostały dokonane poza portem macierzystym przez kapitana na mocy jego ustawowych pełnomocnictw, bez względu na to czy był on równocześnie właścicielem statku, dostawcą, naprawiającym, pożyczającym, czy też pełnił inną rolę jako kontrahent. Umowy i transakcje miały dotyczyć rzeczywistych potrzeb konserwacji statku lub kontynuowania podróży (art. 2 ust. 5).

Zgodnie z art. 5 konwencji wierzytelności powstałe podczas tej samej podróży uprzywilejowane są w takiej samej kolejności, jak wynika ona z wyżej wymienionego art. 2 konwencji. Co więcej, wierzytelności odnoszące się do tego samego zdarzenia uważano za powstałe równolegle. Dodać również należy, iż w myśl przepisu art. 5 konwencji wierzytelności wymienione w ust. 3 i 5 miały być spłacane w odwrotnej kolejności do dat ich powstania, bowiem uprzywilejowane wierzytelności z ostatniej podróży miały pierwszeństwo przed wierzytelnościami z poprzednich podróży (art. 6).

Przywileje wygasały po upływie jednego roku. Powyższy przepis nie dotyczył wierzytelności za dostawy wymienione w art. 2 ust. 5, jeśli termin tychże dostaw mógł przekroczyć sześć miesięcy. Termin przedawnienia w zależności od rodzaju wierzytelności rozpoczynał bieg od dnia powstania należności lub od dnia wymagalności wierzytelności (zob. art. 9). Zgodnie z art. 14 przepisy konwencji miały zastosowanie w każdym Umawiającym się państwie, jeżeli obciążony wierzytelnościami statek przynależał do jednego $\mathrm{z}$ tychże państw oraz $\mathrm{w}$ innych przypadkach przewidzianych $\mathrm{w}$ ustawodawstwie wewnętrznym poszczególnych państw. Powyższa zasada nie naruszała prawa państw umawiających się do niestosowania postanowień konwencji wobec obywateli państwa umawiającego się. Ponadto postanowienia konwencji nie naruszały prawa Państw do zachowania $\mathrm{w}$ ich ustawodawstwie przepisów wymagających od kapitana dopełnienia specjalnych formalności przy zasięganiu pewnych pożyczek pod zastaw statku lub przy sprzedaży ladunku (art. 11).

Porównując obowiązujące w międzywojennej Polsce przepisy dotyczące przywileju morskiego z regulacjami międzynarodowymi widać wyraźną rozbieżność zarówno w hierarchii przywilejów morskich, jaki w treści katalogu wierzytelności uprzywilejowanych. Polskie ustawodawstwo jest w tym zakresie bardziej rozbudowane, co świadczy o ogromnym znaczeniu przywilejów morskich.

Podsumowanie. Przywilej na statku, jako rzeczowe zabezpieczenie wierzytelności prowadził do umocnienia pozycji określonych wierzycieli względem innych, przede wszystkim względem wierzycieli hipotecznych [więcej na temat: 14 , s. 69-76; por. 13 , s. 49, s. 56-60]. Ponadto dawał uprzywilejowanym wierzycielom prawo zaspokojenia ze ściśle określonego statku, lecz nie uprawniał ich do jego posiadania. Przywilej morski cechował się akcesoryjnością i zabezpieczał 
tylko określone wierzytelności. Zaś sam fakt, iż powstawał z mocy prawa i był skuteczny nawet przeciwko nabywcy w dobrej wierze, a przy tym bez względu na istnienie osobistej odpowiedzialności właściciela lub armatora odróżniał przywileje na statku od innych praw rzeczowych [por. 13, s. 55].

Właściwość prawa dla danego wierzyciela uprzywilejowanego lub hipotecznego określało jego obywatelstwo, stąd trudności w stosowaniu prawa w zakresie omawianej instytucji ściśle wiązały się kolizyjnością poszczególnych porządków prawnych. Co więcej, obciążanie statku przywilejami morskimi zmieniało się wraz ze zmianą bandery statku, to zaś miało wpływ na zmianę treści dotychczasowego stosunku prawnego. Zaznaczyć bowiem należy, iż w teorii prawa morskiego statek handlowy pływający pod banderą danego państwa [zob. 4; por. 26, s. 37-39; por. 11, s. 11-13] stanowił „przedłużenie” jego terytorium. Problematyka stosowania przywilejów morskich wynikała zatem ze zróżnicowania prawa prywatnego międzynarodowego poszczególnych państwach trudniących się handlem morskim. Zaznaczyć należy, iż powstawanie przywilejów morskich z mocy prawa uniemożliwiało umowne i trwałe określenie treści stosunku prawnego. Tym celom służyła instytucja hipoteki morskiej, która ustępowała pierwszeństwa przywilejom morskim powstającym z mocy prawa. Powyższe okoliczności wpływały na potrzeba ochrony wierzycieli, szczególnie hipotecznych poprzez wprowadzenie ujednoliconych regulacji międzynarodowych, które miały zapewnić poczucie stabilności morskiego obrotu handlowego [por. 14, s. 26-27].

\section{Bibliografia:}

1. Konwencja międzynarodowa o ujednoliceniu niektórych zasad, odnoszących się do przywilejów i hipotek morskich, podpisana w Brukseli dnia 10 kwietnia 1926 r., Dz. U. Nr 33 poz. 260.

2. Ustawa z dnia 3 czerwca 1919 roku o komisji kodyfikacyjnej (Dz. Praw Państwa Polskiego Nr 44, poz. 315.

3. Ustawa z dnia 1 sierpnia 1919 r. o zarządzie byłej dzielnicy pruskiej, Dz. Praw Państwa Polskiego Nr 64 poz. 385.

4. Ustawa z dnia 28 maja 1920 r. o statkach handlowych morskich, Dz. U. $\mathrm{Nr} 47$ poz. 285.

5. Ustawa z dnia 2 sierpnia 1926 r. o prawie właściwem dla stosunków prywatnych międzynarodowych, Dz. U. 1926, Nr 101, poz. 581.

6. Ustawa z dnia 20 lutego $1936 \mathrm{r}$. w sprawie ratyfikacji międzynarodowej konwencji o ujednoliceniu niektórych zasad, odnoszących się do przywilejów i hipotek morskich, podpisanej w Brukseli dnia 10 kwietnia 1926 r., Dz. U. Nr 15 poz. 137.

7. Ustawa z dnia 1 grudnia 1961 r. Kodeks morski, Dz. U. Nr 57 poz. 318. 
8. Komisja Kodyfikacyjna. Sprawozdanie Prezydenta Komisji Kodyfikacyjnej za czas od 1 czerwca 1932 do 31 marca 1934. Warszawa 1934. Z. 16.

9. Komisja Kodyfikacyjna. Sprawozdanie Prezydenta Komisji Kodyfikacyjnej za czas od 1 czerwca 1934 do 31 marca 1937. Warszawa 1937. Z. 17.

10. Niemiecki kodeks handlowy z dnia 10. Maja 1897, z uwzględnieniem ustaw uzupełniających oprac. Zborowski T., Poznań 1912.

11. Polskie Przepisy Morskie oprac. Toczyski Z., Warszawa 1933.

12. Zbiór ustaw ziem zachodnich Tom XVIII. Handlowe i prywatne prawo morskie obowiązujące w Polsce oraz przepisy o polskich statkach handlowych, Poznań 1925.

13. Adamczak W., Pojęcie $i$ charakter prawny przywilejów na statku, „Zeszyty Naukowe Wydziału Prawa i Administracji. Prawo 1977, nr 5, s. 49-61.

14. Adamczak W., Godecki Z., Przywileje na statku i hipoteka morska, Gdańsk 1988.

15. Adamczyk W., Statek państwowy jako przedmiot przywilejów morskich, „Przegląd Ustawodawstwa Gospodarczego”, R. XXIX, 1976, nr 4 (334), s. 97-101.

16. Adamczak W., Zarys historii przywilejów na statku, „Zeszyty Naukowe Wydziału Prawa i Administracji. Prawo 1974, nr 2, s. 7-15.

17. Dworas-Kulik J., Hipoteka morska w Polsce w okresie międzywojennym w druku.

18. Jastrzębski R., Prawo Prywatne międzydzielnicowe. Zarys problematyki, „Krakowskie Studia z Historii Państwa i Prawa”, R. 8, 2015, nr 3, s. 277-298.

19. Kruczalak K., Morskie prawo handlowe. Zagadnienia wybrane, Gdańsk Szczecin 1992.

20. Leksykon prawa morskiego. 100 podstawowych pojęć, red. Pyć D, Zużewicz-Wiewiórowska I. Warszawa 2013, s. 498-502.

21. Łopuski J., Encyklopedia podręczna prawa morskiego, Gdańsk 1982, s. 91 .

22. Łopuski J., Odpowiedzialność za szkodę w żegludze morskiej, Gdańsk 1969.

23. Matysik S., Podręcznik prawa morskiego, Warszawa 1967.

24. Rydlichowska D., Przywilej morski a odpowiedzialność armatora majątkiem morskim. Studia Iuridica Toruniensia XVII/ 2015, s. 219-238.

25. Sowiński W., Konwencje Brukselskie z 1924 r. i 1926 r. dotyczace prawa morskiego, Warszawa 1938.

26. Sowiński W., Prawo handlowe morskie w zarysie, Lwów 1935.

27. Zoll F., Prawo prywatne międzynarodowe i międzydzielnicowe, Odbitka $\mathrm{z}$ „Encyklopedji Podręcznej Prawa Prywatnego”, z. 15 i 16, Warszawa 1936, s. 4-53.

(C) Dworas-Kulik J., 2018 